\title{
ANALISIS PERBANDINGAN METODE FUZZY INFERENSI SISTEM TSUKAMOTO DAN MAMDANI DALAM PENENTUAN ESTIMASI JUMLAH PRODUKSI GULA
}

\author{
Widiya Anggraeni Hadiyanti, Anton Setiawan Honggowibowo, Maya Suhayati \\ Jurusan Teknik Informatika \\ Sekolah Tinggi Teknologi Adisutjipto Yogyakarta \\ informatika@stta.ac.id
}

\begin{abstract}
PT Madu Baru Yogyakarta s a company that produces sugar. Many factors must be considered in determining the mount of production generated annually. For that, in determining the mount of production per year required and analysis of decision support systems analysis will be done applying Method of Fuzzy Inference System Tsukamoto end Method Inference System Mamdani using the min as function of its implications, the from each rule give nextplicitly (scrip) by the smallest degree of membership (Defuzzufikasi), the final result by applying a weighted average for Fuzzy Inference System defuzzyfikasi begins the composition rules between Max and the Method apllied taking the center point $\left(z^{*}\right)$ fuzzy area. With the comparison method of Fuzzy Inference System and Method of Fuzzy Inference System Mamdani, obtained the most appropriate methods and approaches in determining the estimated amount of sugar production, in order to obtain an output that is the amount of sugar per year.With statistical tests, it can be concluded that the method is relatively close to the calculation method of the factory is Tsukamoto, because the method of Tsukamoto had a lower mean than the mean on the 7,960.42 Mamdani methods is 21710.14.
\end{abstract}

Keywords : Analysis, Fuzzy Logic Inference System Tsukamoto and Mamdani, the determination of the estimate

\section{Pendahuluan}

Suatu perkembangan teknologi tidak terlepas dari adanya langkah penerapan metode yang tepat untuk mendukung kemajuan teknologi tersebut. Seperti halnya dalam penentuan estimasi jumlah produksi dalam perusahaan merupakan suatu hal yang harus diperhatikan sebelum memulai sebuah proses produksi. Perlu dipertimbangkan berbagai faktor untuk menentukan jumlah produksi barang, untuk menghindari resiko perusahaan. Oleh karena itu, diperlukan suatu pertimbangan matang dalam mengelola produksi barang. Untuk itulah diperlukan sebuah aplikasi untuk memberikan alternatif keputusan dalam menentukan estimasi jumlah produksi gula. Pertimbangan itu antara lain jumlah permintaan, biaya produksi, efisiensi mesin, persediaan yang ada, jumlah bahan baku. Sehingga, diperlukan suatu DSS untuk membantu para manajer dalam menentukan jumlah produksi tersebut.

Logika fuzzy merupakan suatu metode yang berbasiskan perasaan yang mampu memberikan solusi lebih seimbang. Logika ini merupakan suatu cara yang tepat untuk memetakan suatu ruang input ke dalam suatu ruang output, sifatnya yang fleksibel sehingga dapat membangun dan mengaplikasikan pengalaman-pengalaman para pengambil 
keputusan secara langsung tanpa harus melalui proses pelatihan. Pada logika fuzzy ini himpunannya memiliki derajat keanggotaan antara 0 sampai 1, sehingga lebih seimbang dalam mengambil suatu keputusan.

PT. Madu Baru Yogyakarta merupakan suatu perusahaan yang bergerak di bidang industri yaitu salah satunya memproduksi gula pasir. Banyak sekali faktor yang harus dipertimbangkan dalam menentukan berapa jumlah produksi yang harus dihasilkan pertahunnya yang akan dijadikan target dalam memulai sebuah usaha. Untuk itu, dalam menentukan target jumlah produksi pertahun dibutuhkan sebuah DSS untuk mengelola dan memanajemen segala sumber daya yang ada sehingga suatu produksi dapat berjalan dengan efektif dan efisien. Dalam pembuatan DSS ini akan dilakukan dengan menerapkan logika fuzzy dalam mengelola faktor-faktor yang menentukan jumlah produksi tersebut yaitu Luas lahan (Ha), jumlah tebu digiling $(\mathrm{Ku})$, rendemen $(\%)$, biaya produksi (Rp). Faktor-faktor tersebut akan dijadikan suatu masukan kemudian diproses dengan logika fuzzy dengan membandingkan metode Fuzzy Inferensi System Tsukamoto dan metode Fuzzy Inferensi System Mamdani pada kasus Estimasi Jumlah Produksi Gula pada pabrik PT. Madu Baru. Diharapkan dengan adanya perbandingan dua metode ini, didapatkan metode yang tepat dan paling mendekati dalam menentukan estimasi jumlah produksi gula, sehingga diperoleh suatu keluaran yaitu jumlah produksi gula per tahunnya.

\section{Gambaran Umum Perusahaan}

PT.Madubaru yang berkedudukan di Daerah istimewa Yogyakarta bergerak dibidang Agro Industri, yang merupakan satu-satunya Pabrik Gula dan Pabrik Spiritus di DIY yang mengemban tugas untuk mensukseskan program pengadaan pangan Nasional khususnya gula pasir dan sebagai perusahaan padat karya PT.Madubaru juga menampung tenaga kerja dari Propinsi DIY.

Lokasi berada di atas lokasi Bangunan Pabrik Gula Padokan (satu di antara dari 17 Pabrik Gula di Daerah Istimewa Yogyakarta yang dibangun Pemerintah Belanda, tetapi dibumihanguskan pada masa Pemerintah Jepang), yang terletak di Desa Padokan, Kelurahan Tirtonirmolo, Kecamatan Kasihan, Kabupaten Bantul, Propinsi Daerah Istimewa Yogyakarta. Kontraktor utama adalah Machine Fabriek Sangerhausen, Jerman Timur. Status perusahaan adalah Perseroan Terbatas (PT) yang berdiri pada tanggal 14 Juni 1955 dan diberi nama “ Pabrik-Pabrik Gula Madu Baru PT “ (P2G. Madu Baru PT) yang memiliki dua Pabrik antara lain Pabrik Gula (PG) Madukismo dan Pabrik Alkohol/Spiritus (PS) Madukismo.

\section{Mekanisme Perhitungan Hasil Produksi Pabrik}

Dalam perhitungan hasil produksi pabrik, diperlukan menghitung jumlah randemen. Rendemen adalah perbandingan berat gula kristal (sukrosa) terhadap berat tebu yang giling. Rumus perhitungannya :

Rendemen $=($ Hablur $(\mathrm{Ku}) /$ Jumlah Tebu $(\mathrm{Ku})) \times 100 \%$

Setelah didapatkan besarnya rendemen, kemudian dapat di hitung jumlah produksi pabrik per tahunnya dengan rumus 2.1 : 
Jumlah Produksi $=$ Jumlah tebu $(\mathrm{Ku}) \times$ rendemen $(\%) \times 1,003$

\section{Metode Mamdani}

Metode ini sering juga dikenal dengan metode Max-Min. Metode ini diperkenalkan oleh Ebrahim Mamdani pada tahun 1975. Untuk mendapatkan output diperlukan 4 tahapan, yaitu:

a. Pembentukan himpunan fuzzy

Pada Metode Mamdani, baik variable input maupun variable output dibagi menjadi satu atau lebih himpunan fuzzy.

b. Aplikasi fungsi implikasi (aturan).

Pada Metode Mamdani, fungsi implikasi yang digunakan adalah Min

c. Penegasan (defuzzy)

Input dari proses defuzzifikasi adalah suatu himpunan fuzzy yang diperoleh dari komposisi aturan-aturan fuzzy, sedangkan output yang dihasilkan merupakan suatu bilangan pada domain himpunan fuzzy tersebut. Sehingga jika diberikan suatu himpunan fuzzy dalam range tertentu, maka harus dapat diambil suatu nilai crisp tertentu sebagai output

d. Komposisi aturan.

Tidak seperti penalaran monoton, apabila sistem terdiri darinbeberapa aturan, maka inferensi diperoleh dari kumpulan dan korelasi antar aturan. Ada 3 metode yang digunakan dalam melakukan inferensi sistem fuzzy adalah Max (Maximum).

Pada metode maximum, solusi himpunan diperoleh dengan cara mengambil nilai maximum aturan kemudiaan menggunakannya untuk memodifikasi daerah fuzzy dan mengaplikasikannya ke output dengan menggunakan operator OR (Union). Jika semua proposisi telah dievaluasi, maka akan berisi suatu himpunan fuzzy yang merefleksikan kontribusi dari tiap-tiap proposisi. Secara umum dapat dituliskan pada rumus persamaan 2.3:

$$
\mu \mathrm{sf}[\mathrm{xi}]=\max (\mu \mathrm{sf}[\mathrm{xi}], \mu \mathrm{kf}[\mathrm{xi}])
$$

Keterangan :

$\mu \mathrm{sf}[\mathrm{xi}]=$ nilai keanggotaan solusi fuzzy sampai aturan ke-i;

$\mu \mathrm{kf}[\mathrm{xi}]=$ nilai keanggotaan konsekuen fuzzy aturan ke-i;

\section{Metode Tsukamoto}

Pada metode ini setiap konsekuen pada aturan yang berbentuk IF THEN harus direpresentasikan dengan suatu himpunan fuzzy dengan fungsi keanggotaan yang monoton. Sebagai hasilnya output hasil inferensi dari tiap-tiap aturan diberikan secara tegas (crisp) berdasarkan a-predikat (fire strength). Hasil akhirnya diperoleh dengan menggunakan ratarata terbobot (weight average). (Jang, dkk., 1997) (Kusumadewi, 2003). 


\section{Perancangan Sistem}

\section{Data Data Pengamatan}

Tabel 1 Data Pengamatan

\begin{tabular}{|l|l|l|l|r|}
\hline \multicolumn{1}{|c|}{ Tahun } & $\begin{array}{c}\text { Luas Lahan } \\
(\mathrm{Ha})\end{array}$ & \multicolumn{1}{|c|}{$\begin{array}{c}\text { Jml Tebu } \\
(\mathrm{Ku})\end{array}$} & $\begin{array}{c}\text { Hablur } \\
(\mathrm{KU})\end{array}$ & $\begin{array}{c}\text { Biaya Produksi } \\
(\mathrm{Rp})\end{array}$ \\
\hline 2001 & 4.313 & 3.163 .667 & $197.144,90$ & 28.584 .436 \\
\hline 2002 & 4.870 & 3.657 .298 & $239.503,50$ & 27.842 .372 \\
\hline 2003 & 4.800 & 3.686 .441 & 246.810 & 29.765 .134 \\
\hline 2004 & 4.295 & 3.585 .520 & $236.825,20$ & 29.307 .872 \\
\hline 2005 & 5.472 & 4.684 .056 & $304.235,00$ & 42.353 .045 \\
\hline 2006 & 5.268 & 4.756 .231 & $319.768,00$ & 40.148 .144 \\
\hline 2007 & 5.250 & 5.341 .260 & $381.088,90$ & 54.619 .911 \\
\hline 2008 & 5.535 & 5.640 .000 & $337.968,00$ & 55.735 .245 \\
\hline 2009 & 6.680 & 4.780 .076 & $325.042,80$ & 52.272 .949 \\
\hline 2010 & 6.597 & 5.234 .137 & $296.398,10$ & 73.437 .944 \\
\hline
\end{tabular}

Data-data yang digunakan dalam pembutaan Sistem Pendukung Keputusan Estimasi Jumlah Produksi Gula Dengan Logika Fuzzy ini diambil dari pengumpulan data di PT. Madu Baru Yogyakarta, data-data tersebut terdiri dari data tentang Luas Lahan yang digunakan untuk menanam tebu, Jumlah Tebu yang digiling, jumlah Hablur, dan Biaya Produksi tebu yang dikumpulkan berdasarkan hasil per tahun antara tahun 2001 sampai target tahun 2010. Data-data tersebut pada Tabel 1.

\section{Nilai Jumlah Produksi Pabrik}

Tabel 2 Jumlah Produksi Pabrik

\begin{tabular}{|l|l|}
\hline \multicolumn{1}{|c|}{ Tahun } & \multicolumn{1}{c|}{ Jml Produksi } \\
\hline 2001 & $197.736,33$ \\
\hline 2002 & $240.222,01$ \\
\hline 2003 & $247.550,43$ \\
\hline 2004 & $237.535,68$ \\
\hline 2005 & $305.147,71$ \\
\hline 2006 & $320.727,30$ \\
\hline 2007 & $382.232,17$ \\
\hline 2008 & $338.981,90$ \\
\hline 2009 & $326.017,93$ \\
\hline 2010 & $297.287,29$ \\
\hline
\end{tabular}

Untuk mendapatkan hasil produksi gula per tahunya, maka perlu menghitung mencari rendemen terlebih dahulu, dengan melihat contoh tabel 3.1 pada tahun 2010 yaitu

Rendemen $\quad=($ Hablur $(\mathrm{Ku}) /$ Jumlah Tebu $(\mathrm{Ku})) \times 100 \%$

$=(296.398,10$ Kuintal / 5.234.137 Kuintal $) \times 100 \%$ 


$$
=5,66 \%
$$

Setelah didapatkan besarnya rendemen, kemudian dapat di hitung jumlah produksi pabrik per tahunya

Jumlah Produksi $=$ Jumlah tebu $(\mathrm{Ku}) \times$ rendemen $(\%) \times 1,003$

$$
\begin{aligned}
& =5.234 .137 \text { Kuintal } \times(5,66 / 100) \times 1,003 \\
& =297.287,29 \text { Kuintal }
\end{aligned}
$$

Setelah dihitung menggunakan rumus pabrik, maka didapatkan jumlah produksi pertahunnya, pada tabel 2 .

\section{Diagram Konteks}

Penggunaan diagram konteks bertujuan memudahkan dalam melihat arus data dalam sistem.

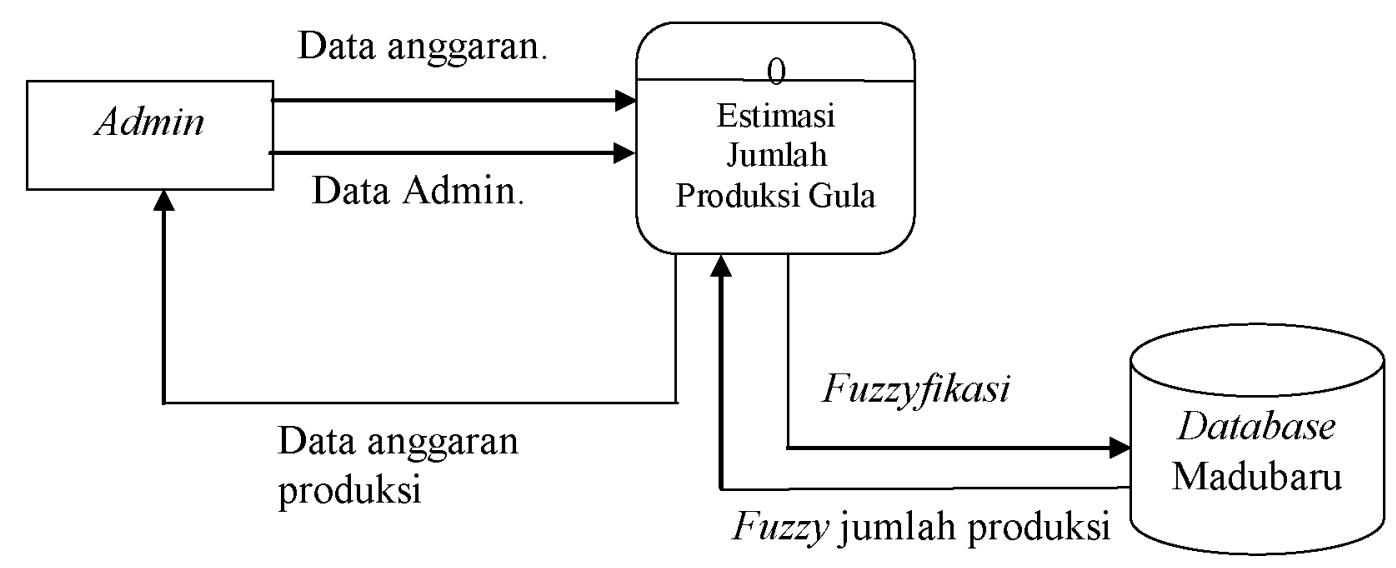

Gambar 1 Diagram Konteks

Pada gambar 1, diagram konteks hanya mempunyai satu entitas yaitu admin. Pada sistem ini, admin menginputkan data admin dan data anggran kedalam sistem estimasi jumlah produksi gula, kemudian sistem menyimpan hasil fuzzifikasi ke dalam database madubaru. Dari database madubaru sistem memberikan informasi berupa jumlah produksi hasil fuzzyfikasi.

\section{DAD Level 1}

Diagram Alir Data level 1 Aplikasi Analis Perbandingan Metode Fuzzy Inferensi System Tsukamoto dan Mamdani Dalam Penentuan Estimasi Jumlah Produksi Gula. Proses yang terjadi adalah isi data yaitu admin mengisi data admin yang disimpan ke dalam data store 'admin', data anggaran yang disimpan dalam data store 'anggaran', data store 'anggaran' adalah proses pengolahan data untuk menghitung fuzzifikasi dari tiap-tiap metode, kemudian hasi fuzzifikasi di simpan dalam data store 'tamp' yang kemudian diproses lihat data SPK senhingga dapat memberikan informasi kepada admin berupa estimasi jumlah produksi gula hasil fuzzifikasi. 


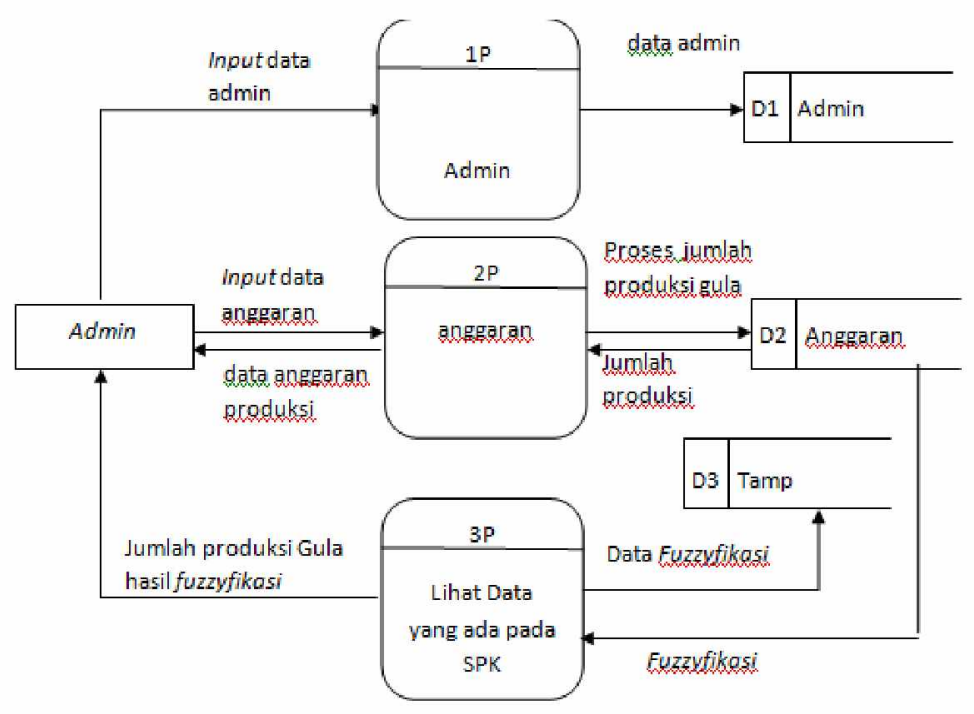

Gambar 2 Diagram Alir Data (DAD) Level 1

\section{FlowChart System}

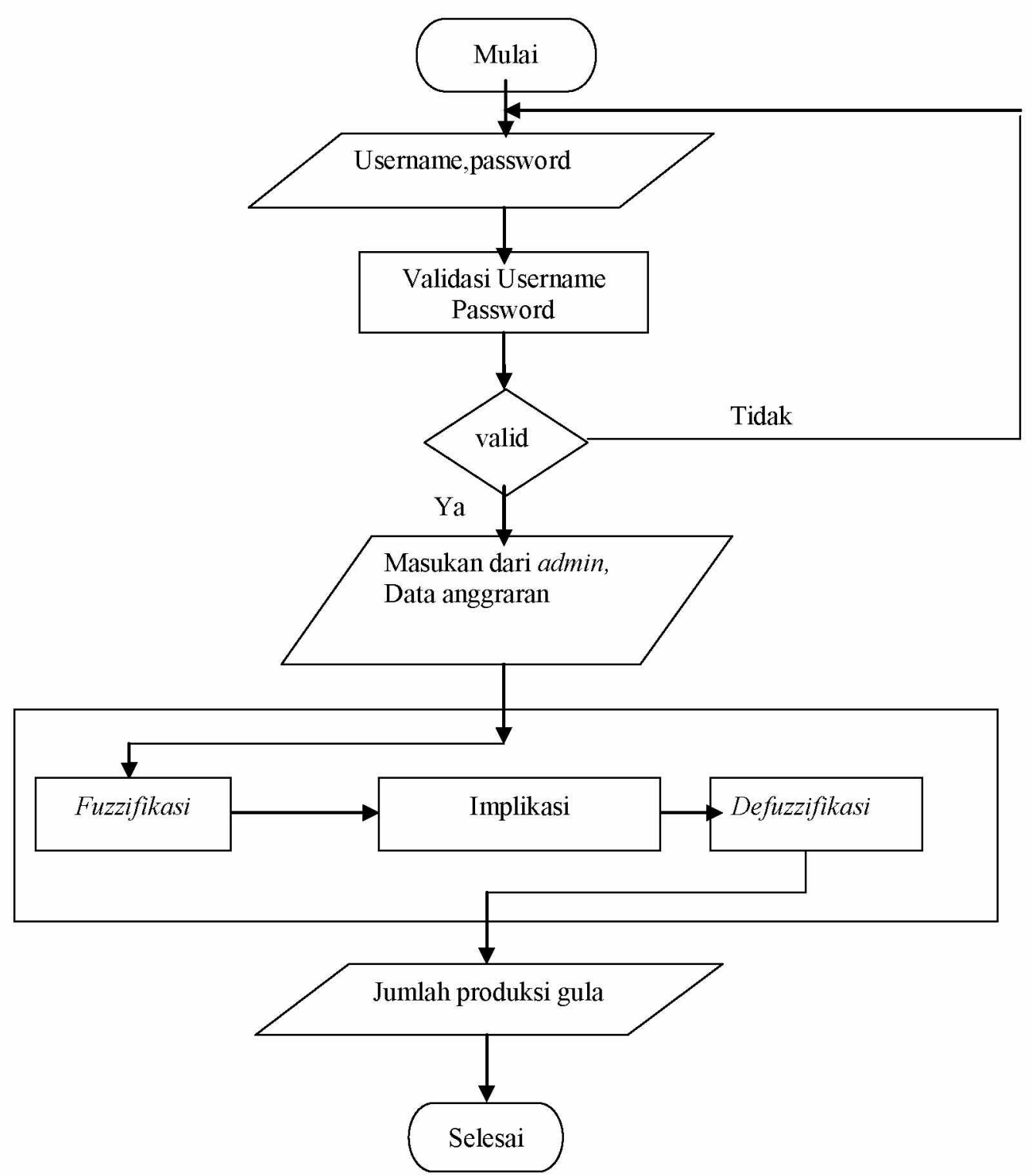

Gambar 3 FlowChart SPK Jumlah Produksi Gula dengan Logika Fuzzy 
Suatu permasalahan dapat diselesaikan dengan flowchart, karena flowchart merupakan bagan alir dari proses penyelesaian masalah yang disusun secara sistematis. Untuk menggambarkan keseluruhan langkah kerja dan sistem yang akan dibuat, maka digunakan bagan alir atau flowchart. Dalam Analisis Estimasi Jumlah Produksi Gula, entitas yang berkaitan adalah admin. Pada Admin didahului dengan menginputkan user dan password. Apabila Login admin sukses maka langsung menuju ke halaman menu, dimana terdapat proses penginputan data admin dan data anggaran, kemudian perhitungan estimasi jumlah produksi gula di proses melalui peroses fuzzifikasi, implikasi dan defuzzifikasi untuk menghasilkan estimasi jumlah produksi gula. Simulasi estimasi jumlah produksi gula diakhiri dengan melakukan proses keluar atau log out oleh admin.

\section{Implementasi Dan Analisa Sistem}

Tahap implementasi sistem merupakan tahap pendiskripsian suatu sistem aplikasi agar sistem aplikasi tersebut siap untuk dioperasikan. Tahap ini dilakukan setelah tahap analisis data, tahap perancangan basis data dan tahap perancangan aliran data dan menu sistem selesai. Tahap implementasi tersebut akan membahas mengenai desain input data, desain proses data, desain output sistem serta analisis hasil yang berupa pengujian sistem tersebut secara manualnya. Berdasarkan tahapan implementasi tersebut diketahui apakah sistem yang dibuat benar-benar mencapai tujuan yang diinginkan. Sebelum sistem ini diimplementasikan maka sistem harus bebas dari kesalahan. Kesalahan yang mungkin terjadi antara lain kesalahan dalam penulisan bahasa pemrograman, kesalahan logika baik program maupun pengolahan data, maupun kesalahan pada waktu melakukan proses.

Berdasarkan analisis dari desain sistem yang telah dilakukan, maka telah diimplementasikan sebuah Analisis Perbandingan Inferensi Sistem Tsukamoto dan Mamdani Dalam Penentuan Estimasi Jumlah Produksi Gula. Dalam penyusunan sistem ini digunakan bahasa pemrograman Delphi 7.0 dan database PostgreSQL yang merupakan pasangan bahasa pemrograman dan basis data yang digunakan untuk merancang suatu aplikasi . Sistem ini dilengkapi dengan tombol-tombol perintah peng-input-an data sehingga dapat membantu admin dalam mengoperasikan sistem dan akan didapatkan hasil output perbandingan jumlah produksi gula tiap tahunnya, selain itu tombol-tombol tersebut akan membantu sistem dalam melakukan tugasnya dengan mudah dan cepat.

\section{Analisa Perbandingan Hasil Penerapan Metode Tsukamoto dan Mamdani Untuk Estimasi Jumlah Produksi Gula}

Analisa perbandingan estimasi jumlah produksi gula per tahun menggunakan contoh kasus dengan masukan tahun 2008, 2009 dan 2010 maka didapatkan hasil perhitungan berikut ini.

1. Perhitungan manual pabrik

Tahun $2008=338.981,90$ Kuintal

Tahun $2009=326.017,93$ Kuintal

Tahun $2010=297.287,29$ Kuintal

2. Penerapan menggunakan fuzzy Tsukamoto

Tahun $2008=297.348$ Kuintal

Tahun $2009=308.864,92$ Kuintal 
Tahun $2010=320693,62$ Kuintal

3. Penerapan menggunakan fuzzy Mamdani

Tahun $2008=278.857,085$ Kuintal

Tahun $2009=303.600,244$ Kuintal

Tahun $2010=313,299.377$ Kuintal

Selain itu, sistem SPK Perbandingan Estimasi Jumlah Produksi Gula dengan Logika Fuzzy Tsukamoto dan Mamdani tersebut dibandingkan dengan perhitungan pabrik yang diperoleh dari PT. Madu Baru Yogyakarta pada tahun 2000-2008. Tabel 3 berikut ini menjelaskan hasil dari sistem jika dibandingkan dengan data-data pengamatan produksi pada tahun 2000 .

Tabel 3 Data Perbandingan Estimasi Jumlah Produksi Gula

\begin{tabular}{|c|c|c|c|c|c|c|c|}
\hline Th & $\begin{array}{c}\text { Luas } \\
\text { Lahan } \\
(\mathrm{Ha})\end{array}$ & $\begin{array}{c}\text { Jml Tebu } \\
(\mathrm{Ku})\end{array}$ & $\begin{array}{c}\text { Rende } \\
\text { men } \\
(\%)\end{array}$ & $\begin{array}{c}\text { Biaya } \\
\text { Produksi } \\
(\mathrm{Rp})\end{array}$ & $\begin{array}{c}\text { Jml } \\
\text { Produksi }\end{array}$ & Tsukamoto & Mamdani \\
\hline 2001 & 4.313 & 3.163 .667 & 6,23 & 28.084 .436 & $197.736,33$ & $284.559,53$ & $278.302,67$ \\
\hline 2002 & 4.870 & 3.657 .298 & 6,55 & 27.842 .372 & $240.222,01$ & $283.157,11$ & $289.452,21$ \\
\hline 2003 & 4.800 & 3.686 .441 & 6,70 & 29.765 .134 & $247.550,43$ & $279.376,12$ & $253.833,41$ \\
\hline 2004 & 4.295 & 3.585 .520 & 6,61 & 29.307 .872 & $237.535,68$ & $275.233,26$ & $264.241,22$ \\
\hline 2005 & 5.472 & 4.684 .056 & 6,50 & 42.353 .045 & $305.147,71$ & $295.506,78$ & $221.785,76$ \\
\hline 2006 & 5.268 & 4.756 .231 & 6,72 & 40.148 .144 & $320.727,30$ & $295.075,67$ & $220.012,79$ \\
\hline 2007 & 5.250 & 5.341 .260 & 7,13 & 54.619 .911 & $382.232,17$ & $301.020,39$ & $250.763,29$ \\
\hline 2008 & 5.535 & 5.640 .000 & 5,99 & 55.735 .245 & $338.981,90$ & $297.348,11$ & $279.770,21$ \\
\hline 2009 & 6.680 & 4.780 .076 & 6,79 & 52.272 .949 & $326.017,93$ & $300.796,02$ & $304.828,23$ \\
\hline 2010 & 6.597 & 5.234 .137 & 5,66 & 73.437 .944 & $297.287,29$ & $320.693,63$ & $313.178,53$ \\
\hline
\end{tabular}

\section{Analisa Perbandingan Menggunakan Uji Statistik}

1. Perbandingan perhitungan Pabrik dengan Metode Tsukamoto

Hasil perhitungan pabrik dan Metode Tsukamoto, kemudian di uji menggunakan sofware SPSS, sehingga menghasilkan output :

Tabel 4 Paired Sample Statistic Pabrik dan Tsukamoto

\begin{tabular}{|c|c|c|c|c|c|}
\hline & & Wean & $N$ & Std. Deviation & $\begin{array}{c}\text { Std. Error } \\
\text { Mean }\end{array}$ \\
\hline & Pabrik & 2893439 & 10 & 56735.85446 & 17941.45 \\
\hline 1 & Tsukamoto & 293076.7 & 10 & 13452.11764 & 4253.933 \\
\hline
\end{tabular}

Tabel 5 Paired Sample Corelation Pabrik dan Tsukamoto

\begin{tabular}{|c|c|c|c|}
\hline & $\mathbf{N}$ & Correlation & Sig. \\
\hline Pair 1 Pabrik \& Tsukamoto & 10 & 655 & .040 \\
\hline
\end{tabular}


Hasil uji menunjukkan bahwa korelasi antara dua variabel adalah sebesar 0.655 dengan sig sebesar 0.040. Hal ini menunjukkan bahwa korelasi antara perhitungan pabrik dan Metode Tsukamoto dalam penentuan estimasi jumlah produksi gula adalah kuat dan signifikan.

Sehingga didapatkan hipotesis untuk perhitungan pabrik dan Metode Tsukamoto pada estimasi jumlah produksi gula yaitu :

Ho : Perhitungan Pabrik dan Metode Tsukamoto dalam penentuan estimasi jumlah produksi gula adalah identik sama

Hi : Perhitungan Pabrik dan Metode Tsukamoto dalam penentuan estimasi jumlah produksi gula adalah tidak identik.

Hasil Uji Hipotesis terdapat pada tabel 6

Tabel 6 Paired Sample Test Pabrik dan Tsukamoto

\begin{tabular}{|c|c|c|c|c|c|c|c|c|}
\hline & \multicolumn{5}{|c|}{ Paired Differentices } & \multirow[b]{3}{*}{ t } & \multirow[b]{3}{*}{ df } & \multirow[b]{3}{*}{ Sig (2-tailed $)$} \\
\hline & \multirow[b]{2}{*}{ Mean } & \multirow[b]{2}{*}{ Std. Devilation } & \multirow{2}{*}{$\begin{array}{c}\text { Std. Errop" } \\
\text { Meatr }\end{array}$} & \multicolumn{2}{|c|}{$\begin{array}{c}95 \% \text { Confidence } \\
\text { Interval of the } \\
\text { Differences }\end{array}$} & & & \\
\hline & & & & Loimer & Upper & & & \\
\hline Fajir I Pabrik-Tsukamoto & .373281 & 4896606632 & 15490.75 & .307753 & 31319.71 & .241 & 9 & 815 \\
\hline
\end{tabular}

Hasil korelasi antara variabel pabrik dan tsukamoto menghasilkan nilai $\mathrm{t}$ hitung adalah sebesar -0,241 degan sig 0.04 (tabel 5) dengan nilai probabilitas dibawah 0,05. Hal ini menyatakan bahwa korelasi antara perhitunagn pabrik dan metode Tsukamoto dalam penentuan estimasi jumlah produksi gula adalah identik sama.

Dari tabel $t$ dengan $\mathrm{df}=9$, didapat angka 2,2622

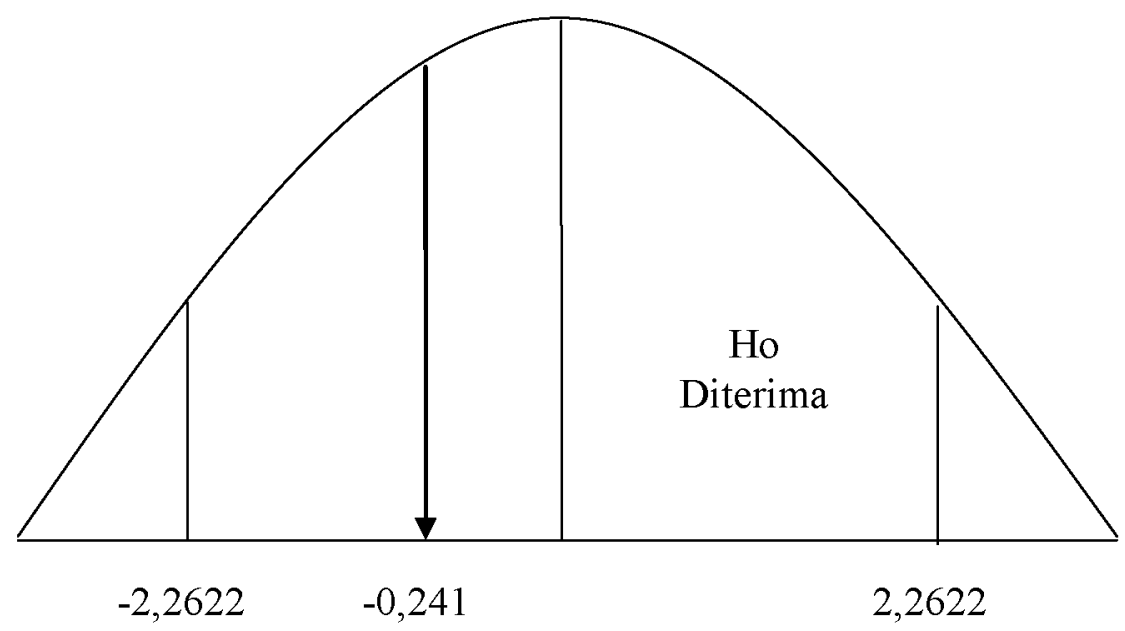

Gambar 4 Hasil Uji Paired Sample Test Perhitungan Pabrik dan Tsukamoto

Karena $\mathrm{t}$ hitung terletak pada daerah Ho diterima, maka dapat simpulkan bahwa perhitungan pabrik dan Metode Tsukamoto dalam penentuan estimasi jumlah produksi gula adalah identik sama (tidak jauh berbeda). 
2. Perbandingan perhitungan Pabrik dengan Metode Mamdani

Hasil perhitungan pabrik dan Metode Tsukamoto, kemudian di uji menggunakan sofware SPSS, sehingga menghasilkan output :

Tabel 7 Paired Sample Statistic Pabrik dan Mamdani

\begin{tabular}{|ll|l|r|r|c|}
\hline & & Mean & N & Std. Deviation & $\begin{array}{c}\text { Std. Error } \\
\text { Wean }\end{array}$ \\
\hline Pair & Pabrik & 289343.9 & 10 & 56735.85446 & 17941.45 \\
1 & Mamdani & 267616.8 & 10 & 31712.74413 & 10028.45 \\
\hline
\end{tabular}

Tabel 8 Paired Sample Corelation Pabrik dan Mamdani

\begin{tabular}{|ll|r|r|c|}
\hline & \multicolumn{1}{|c|}{ N } & Correlation & Sig. \\
\hline Pair 1 & Pabrik \& Mamdani & 10 & -.170 & .638 \\
\hline
\end{tabular}

Hasil uji menunjukkan bahwa korelasi antara dua variabel adalah sebesar -0.170 dengan sig sebesar 0.638. Hal ini menunjukkan bahwa korelasi antara perhitungan pabrik dan Metode Mamdani dalam penentuan estimasi jumlah produksi gula adalah kuat dan signifikan.

Sehingga didapatkan hipotesis untuk perhitungan pabrik dan Metode Tsukamoto pada estimasi jumlah produksi gula yaitu :

Ho : Perhitungan Pabrik dan Metode Mamdani dalam penentuan estimasi jumlah produksi gula adalah identik sama

Hi : Perhitungan Pabrik dan Metode Mamdani dalam penentuan estimasi jumlah produksi gula adalah tidak identik.

Hasil Uji Hipotesis terdapat pada tabel 9

Tabel 9 Paired Sample Test Pabrik dan Tsukamoto

\begin{tabular}{|c|c|c|c|c|c|c|c|c|}
\hline & \multicolumn{5}{|c|}{ Faired Differencences } & \multirow[b]{3}{*}{$t$} & \multirow[b]{3}{*}{ df } & \multirow[b]{3}{*}{ Eilg. (2tailed) } \\
\hline & \multirow[b]{2}{*}{ Mean } & \multirow[b]{2}{*}{ Std. Devilation } & \multirow{2}{*}{$\begin{array}{l}\text { Std. Error } \\
\text { Mean }\end{array}$} & \multicolumn{2}{|c|}{$\begin{array}{c}95 \% \text { Confidence } \\
\text { Irteralal of the } \\
\text { Difference }\end{array}$} & & & \\
\hline & & & & Lower & Upper & & & \\
\hline Fair'1 Fabrik-Mamdani & 21727.04 & 69546.80137 & 2199263 & .280237 & 7147783 & .988 & 9 & .349 \\
\hline
\end{tabular}

Hasil korelasi antara variabel pabrik dan Mamdani menghasilkan nilai t hitung adalah sebesar 0,988 degan sig 0.638 (table 5) dengan nilai probabilitas diatas 0,05. Hal ini menyatakan bahwa korelasi antara perhitunagn pabrik dan metode Tsukamoto dalam penentuan estimasi jumlah produksi gula adalah identik tidak sama.

Dari table $\mathrm{t}$ dengan $\mathrm{df}=9$, didapat angka 2,2622 


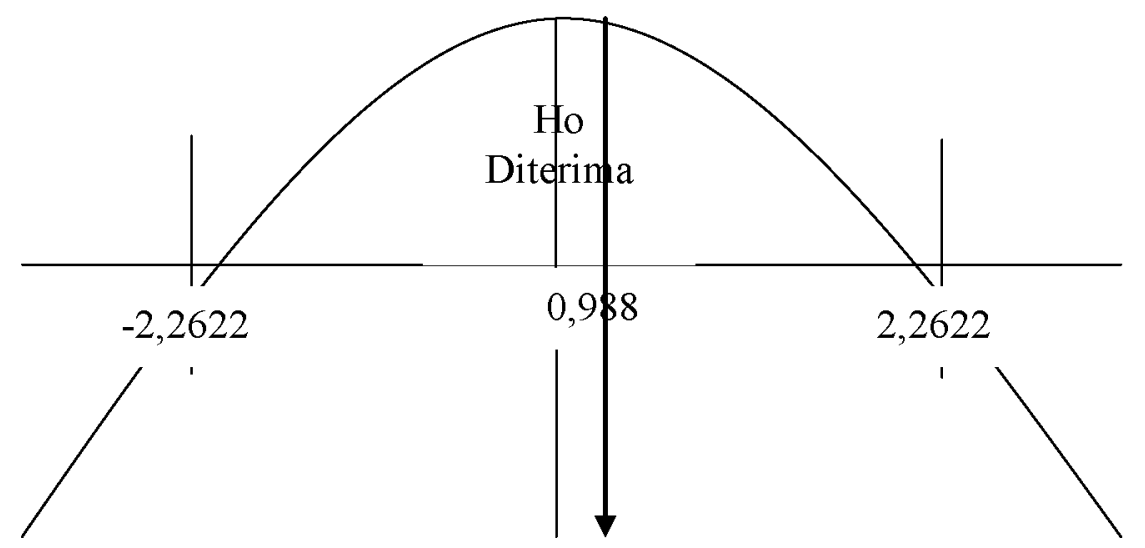

Gambar 5 Hasil Uji Paired Sample Test Perhitungan Pabrik dan Mamdani

Karena $\mathrm{t}$ hitung terletak pada daerah Ho diterima, maka dapat simpulkan bahwa perhitungan pabrik dan Metode Mamdani dalam penentuan estimasi jumlah produksi gula adalah identik sama (tidak jauh berbeda).

Nilai $t$ hitung adalah sebesar 0,988 degan sig 0.349. Karena sig $>0.05$ maka dapat disimpulkan bahwa Ho diterima, perhitungan pabrik dan Metode Mamdani dalam penentuan estimasi jumlah produksi gula adalah identik sama (tidak jauh berbeda).

Berdasarkan hasil kedua uji statistik, perbandingan antara perhitungan pabrik dan Metode Tsukamoto dengan perhitungan pabrik dan Metode Mamdani. Sehingga dapat disimpulkan metode yang relatif mendekati dengan perhitungan pabrik dalam estimasi jumlah produksi gula adalah Metode Tsukamoto, karena Metode Tsukamoto mempunyai mean sebesar $-3732,81$ yang lebih rendah dibandingkan mean pada Metode Mamdani sebesar 21727,04 .

\section{Kesimpulan}

Berdasarkan uji coba dan analisis maka dapat diambil kesimpulan :

1. Sistem Pendukung Keputusan Estimasi Jumlah Produksi Gula merupakan solusi bagi para pengambil keputusan dalam menentukan estimasi produksi gula per tahunnya.

2. SPK Estimasi Jumlah Produksi Gula diproses dengan Logika Fuzzy yang memetakan suatu ruang input ke dalam ruang output dimana yang menjadi input-nya adalah faktorfaktor yang mempengaruhi jumlah produksi gula yang meliputi Luas Lahan, Jumlah Tebu, Rendemen, dan Biaya Produksi kemudian yang dijadikan output-nya adalah Jumlah Produksi Gula per tahunnya. Kemudian dirancang menggunakan Metode Inferensi Tsukamoto dan Metode Inferensi Mamdani.

3. Dengan uji statistik, dapat disimpulkan bahwa metode yang relatif mendekati perhitungan pabrik adalah Metode Tsukamoto, karena Metode Tsukamoto mempunyai mean yang lebih rendah yaitu -7960,42 dibandingkan mean pada Metode Mamdani yaitu 21710,14 . 


\section{Saran}

Sistem ini dapat dikembangkan lagi dengan metode-metode inferensi lainnya misalnya Metode Sugeno. Selain itu metode-metode inferensi ini dapat digunakan untuk memecahkan permasalahan lain selain estimasi jumlah produksi gula.

\section{Daftar Pustaka}

Bin Ladjamudin.,Al-Bahra, 2005, Analisis dan Desain Sistem Informasi, Yogyakarta, Graha Ilmu.

HM., Jogiyanto, 2005, Analisis dan Desain Sistem Informasi: Pendekatan Teori dan Praktek Aplikasi Bisnis, Yogyakarta, Andi Offset

Kusumadewi S. dan Purnomo H., 2010, "Aplikasi Logika Fuzzy untuk Pendukung Keputusan", Yogyakarta, Graha Ilmu

Kristanto, Andri, 2004, Rekayasa Perangkat Lunak (Konsep Dasar), Yogyakarta, Penerbit Gava Media 